\title{
FILOSOFIA E PSICANÁLISE: A LINGUAGEM EM LACAN, APEL E GADAMER.
}

\section{Philosophy and Psychoanalysis: Language in Lacan, Apel and Gadamer.}

Luiz Carlos Santuário ${ }^{1}$

\section{Resumo}

A filosofia, sendo um discurso antípoda ao discurso das ciências, no sentido de que não produz um conhecimento sobre particularidades, situa-se a priori no espaço intemo de uma clivagem e de uma diferença onde este discurso e este saber são produzidos e apresentados. Na cena contemporânea, três pensadores, Lacan, Apel e Gadamer, tematizam a experiência do humano como ligada estritamente à linguagem enquanto elemento estruturador do humano, na medida em que este é situado no interior do espaço de uma dobra e de uma clivagem.

Palavras-chave: Filosofia; Psicanálise; Linguagem.

\section{Abstract}

Philosophy as a speech opposite to the speech of sciences as long as it does not pursue a knwoledge on specialities, it is situated a priori at the intemal space of a fold where this knowledge is produced and presented. At the contemporary scene there are three thinkers, Lacan, Apel and Gadamer which think human experience as deeply linked towards language as the structural frame of the human being, hence he is situated within the space of this fold.

Keywords: Philosophy; Psychoanalysis; Language.

1 Prof. Dr. Universidade de Caxias do Sul. (UCS) - Departamento de Filosofia. RS Brasil. Telefone: (54) 3218-2156 Fax: (54) 3218-2156. Email: santuario2@yahoo.com.br

Revista de Filosofia, Curitiba, v. 17 n.20, p. 147-163, jan./jun. 2005. 
O exercício filosófico somente pode se apresentar e se efetivar como dobra e clivagem na medida em que nele a linguagem não tem a função apenas descritiva, enunciativa e produtora de um saber sobre objetos, mas ela opera numa via de mão dupla pois, ao mesmo tempo em que enuncia algo, pretende, em seu próprio movimento, produzir para o sujeito, e para seu interlocutor, um saber justificado sobre este algo. O saber filosófico não produz conhecimento por somação, como é o caso do saber da ciência e, desta forma, está convocado e condenado a priori a operar no espaço desta dobra e desta clivagem.

A atividade filosófica, enquanto constituinte e privativa do humano, encontra-se desafiada a enfrentar a necessária e urgente suspeita que deva ser dirigida a qualquer tentativa de naturalizar o fenômeno humano, reduzindo-0, por exemplo, a uma feliz combinatória de eventos bioquímicos ${ }^{2}$.

O avanço do conhecimento científico mostrou que esta estruturação bioquímica pode ser conhecida, explicada e, em seguida, manipulada e alterada pela eficiência da técnica de manipulação e recombinação do DNA humano. Neste patamar biologizante, fica excluída toda e qualquer mediação instituída pelo humano, como o pensar, o compreender e o falar. Ficam excluídas as mediações proporcionadas pelo humano e, por conseguinte, o próprio humano torna-se redundante em relação a si mesmo, pois passa a ser dito e compreendido, não mais em seu lugar de origem e constituição, mas no locus metafísico de um discurso científico $^{3}$. A filosofia, por seu turno, apresenta todo um arsenal de estratégias que se colocam como candidatas a produzir uma compreensão mais ampliada do fenômeno humano, para além de qualquer naturalismo.

Quando percorremos o cenário filosófico e examinamos as estratégias de apresentação do espaço da clivagem, da diferença e da dobra na estrutura do humano, vemos que, inicialmente, na metafísica clássica, o humano havia sido definido pela sua capacidade de raciocinar. Esta representação do humano como ser racional, como ser pensante, como cogito, tem sua coroação e refinamento na filosofia moderna, que

2 Como são os argumentos naturalistas do imolador de Darwin, o cientista britânico R. Dawkins, que conceitua o humano apenas como instância de álibi para a perpetuação do mecanismo do DNA. Ver p.ex. The selfish gene e The blind watchmaker.

3 Ver também a refutação filosófica à lógica cega da biologia molecular (STEIN, 2003, p. 519-31).

Revista de Filosofia, Curitiba, v. 17 n.20, p. 147-163, jan./jun. 2005. 
produziu uma série de paradigmas, todos girando em torno da noção de um sujeito possuidor de uma racionalidade autônoma. Temos, assim, a instituição do solipsismo subjetivista de Descartes em que esta racionalidade opera de modo auto-suficiente e imanente e, posteriormente, a invenção do transcendental clássico kantiano e da predicação do espaço do transcendental, do a priori, como terreno e armadura em que e como se efetiva a produção do conhecimento válido para o humano.

Nestes dois filósofos, o estabelecimento do modo e topos do conhecimento opera exemplarmente a partir da subjetividade, da consciência e, por conseguinte, da viciosa dicotomia sujeito-objeto. O kantismo, com sua maquinaria transcendental, embora ainda refém da dicotomia sujeito-objeto, representa um avanço importante no sentido de pensar filosoficamente no interior do espaço da clivagem, da diferença e da dobra em que se constitui o sujeito e o espaço de conhecimento válido para este sujeito. Embora, ainda neste caso, a dobra e a clivagem ainda sejam instituídas pela performance de um cogito. O ganho proporcionado pelo kantismo está em que ele operou uma virada antropológica que obriga o homem a prestar atenção às condições de todo o pensamento e de todo o conteúdo mental que ele possui, portanto, a levar em conta a especificidade da linguagem filosófica e as condições particulares que permitem o filosofar.

A invenção do transcendental clássico, de cunho kantiano, tem sua validade questionada e seu estatuto retificado e alterado pelo aparecimento da fenomenologia hermenêutica de Heidegger, a partir da predicação de um pré-compreender que, desde sempre, acompanha o humano em sua condição de sujeito situado no mundo. A dimensão estruturante, normativa e organizadora passa a ser agora a instância da précompreensão e da finitude, deslocando a esfera de constituição e de estruturação do humano, de um patamar solipsista e ligado a um cogito transcendental, para uma instância fenomenológica e hermenêutica.

O conceito operativo de diferença ontológica na fenomenologia hermenêutica de Heidegger se apresenta, destacadamente, como um locus em que a atividade filosófica se efetiva, se realiza e se consuma como o pensar da diferença e, ao mesmo tempo, o pensar no espaço da diferença. Como leitor atento da obra heideggeriana, Stein pode captar este movimento filosófico através de sua frase capital: Pensar é pensar a diferença (STEIN, 2002). A atividade filosófica, na fenomenologia hermenêutica de Heidegger, opera no espaço em que se desdobra e apare-

Revista de Filosofia, Curitiba, v. 17 n.20, p. 147-163, jan./jun. 2005. 
ce a clivagem e a dobra do humano, enquanto este paradigma realiza a atividade de repor no pensamento e, em seguida, na linguagem, o espaço mesmo da diferença onde se encontra situada a plataforma originária do humano, instituída pelo pré-compreender como moto constituidor do humano, para além de uma racionalidade solipsista e de um ferramental predicado pelo transcendentalismo clássico kantiano. A fenomenologia hermenêutica pretende ter superado o transcendental clássico, ao interpretar o modo privilegiado de acesso ao conhecimento e a verdade como sendo possibilitado e efetivado pelo acesso e desenvolvimento do círculo hermenêutico, onde se mostra e se efetiva a diferença ontológica, círculo no qual esta diferença é pensada e reposta na linguagem.

Desta forma, fica superado e retificado o estelionato gnosiológico que havia sido perpetrado pelo reducionismo do conhecimento científico, que reduziu o conceito de mundo a um conjunto somativo de fenômenos explicáveis e conhecidos através da explicação causal e da aplicação e imposição de um método. O conceito de mundo ressurge aqui com sua dignidade originária, e é compreendido como modo-deser do Dasein e como conjunto de estruturas prévias que permitem 0 modo de ser compreensivo (hermenêutico) e o enunciativo (apofântico).

No espaço posterior ao aparecimento da ontologia fundamental, gerada pela fenomenologia hermenêutica de Heidegger, nos deparamos com uma série de alternativas filosóficas que se ramificam numa miríade de paradigmas e propostas para tematizar a dobra e a clivagem no humano, a diferença e o espaço da diferença. Analisaremos aqui três propostas de pensadores contemporâneos: A proposta de Lacan, na psicanálise pós-freudiana; Apel e a semiótica transcendental e, finalmente, a hermenêutica filosófica de Gadamer.

\section{I - A clivagem do humano na psicanálise de Lacan: o sujeito no interior da dobra (SANTUARIO, 2003; 2004).}

A psicanálise lacaniana articula um conjunto de premissas e conceitos que constituem um sistema de decifração do modo próprio e específico do humano constituir-se como tal; trata-se de uma ontogênese. Assim como há em Heidegger a predicação de uma diferença transcendental entre Ser e ente, o que permite a constituição do terreno propício à construção de uma originalíssima ontologia fundamen-

Revista de Filosofia, Curitiba, v. 17 n.20, p. 147-163, jan./jun. 2005. 
tal, há também em Lacan a predicação de uma diferença transcendental que opera e se institui na origem da formatação de seu sistema de pensamento; a distinção entre o sujeito do conhecimento e o sujeito do significante (LACAN, 1992, p. 45). O sujeito do conhecimento, bastião da legalidade e da legitimidade da empreitada do saber filosófico, é o sujeito cartesiano por excelência, é o sujeito do cogito, o sujeito que pensa e articula o sentido e o significado da realidade em categorias ou conceitos.

De outro lado, o sujeito do significante é o sujeito instalado ab initio na ordem do simbólico e regido pela combinatória do significante.

Contudo, o giro lacaniano é pós-kantiano, pois não há dedução transcendental feita a partir de um cogito cartesiano ou transcendentalmente instituído, dado que não há certeza no Cogito. A certeza está fundada no campo do Outro, enquanto lugar da combinatória significante. Outro traço distintivo entre Kant e Lacan é que a noção de signo em Kant é binária, pois nele a noção de a priori não envolve a noção de código, ou um elemento terceiro da linguagem. Há também a correção da noção de sujeito, pois a descoberta lacaniana implica na produção de um novo estatuto de caracterização e uma nova compreensão da condição humana, na medida em que não é somente o homem que fala, mas, no homem e através do homem, isso fala. (ça parle). $\mathrm{O}$ isso, devendo ser aqui compreendido como a estrutura da linguagem (MULER; RICHARDSON, 1994, p. 334).

Ain da que pareça estar implicado um determinismo inexorável neste perten cimento a priori à cadeia do simbólico e, utilizando o espaço e o conceito metafórico do jogo, devemos ter em conta que o jogo já está jogado, os dados já foram lançados. Já foram lançados, com a seguinte ressalva, podemos retomá-los, e lançá-los mais, ainda... (LACAN, 1987, p. 276).

O falante humano, acoplado à linguagem, nunca pode advir por inteiro na fala, dado que está submetido a partir de então a um imperativo categórico, porém não mais de cunho filosófico e kantiano (LACAN, 1995, p. 863). O imperativo que opera sobre o sujeito é o da plataforma do desejo, sendo o desejo uma falta do ser. Como parlêtre, o falante humano é um fala-ser, uma falta-para-ser, ele é finito, e infinitamente fala. Na linguagem, na fala, ele mostra sua falta, sua finitude. Daí que o humano fica capturado nas malhas de uma báscula eterna entre linguagem e desejo.

Revista de Filosofia, Curitiba, v. 17 n.20, p. 147-163, jan./jun. 2005. 
O ultrapassamento do kantismo efetivado pelo saber lacaniano permite identificar uma analogia e uma afinidade eletiva entre a trajetória da fundamentação filosófica percorrida por Apel, que nos indica o caráter e o estatuto auto-reflexivo do discurso humano e a tese lacaniana da existência e eficácia contra-fática do campo do Outro, como anterior e constituidor do sujeito humano falante.

Trata-se, em ambos os autores, da indicação de um lugar terceiro, a convenção significante (LACAN, 1995, p. 529). Contudo, no caso da psicanálise, diversamente de Apel, trata-se da articulação deste locus terceiro, impossível de ser reinstituído ao nível de um saber manipulável com as ferramentas filosóficas da reflexão transcendental elenquicamente instituída.

Em Apel (1985, P. 71), trata-se de estabelecer a auto-reflexão, como jogo lingǘstico próprio da filosofia. Em Lacan, trata-se do cultivo da perda, da queda, da dívida que nos constitui, em nossa relação originária com o Outro.

Em ambos, trata-se da compreensão de que o acesso ao real é sempre lingüisticamente mediado e de que a relação só é a dois na aparência, na medida em que há sempre, a priori, um lugar terceiro que é a convenção significante (LACAN, 1995, p. 266; 529). Trata-se, portanto, da noção de signo em Lacan como tridimensional topológica, a partir do estabelecimento da prioridade: lógica, ontológica, topológica e semiótica do significante no processo de fundação do sentido, para um sujeito.

Com a indicação destas afinidades eletivas, fica mais próxima de nós a compreensão do estatuto do estranho e provocativo nome, no território da psicanálise, da categoria de inconsciente. $\mathrm{O}$ inconsciente é simplesmente um outro nome para o conhecimento simbólico na medida em que ele é um conhecimento que não se sabe, um conhecimento que o sujeito não sabe que sabe. Ele não reside em nenhum sujeito particular, nem no Outro (que não é um sujeito, mas um lugar), mas é intersubjetivo. Contudo, isto não nos previne de supor que em algum lugar existe um sujeito que possua este conhecimento simbólico (EVANS, 1997, p. 94). ${ }^{4}$

Lacan pretende justificar a ocupação de sua posição de executor testamentário holográfico do significante por ter o significante um

4 Lacan chamará de sujeito suposto saber este sujeito (inexistente) a quem se atribui, por transferência, a posse deste conhecimento. (n.a)

Revista de Filosofia, Curitiba, v. 17 n.20, p. 147-163, jan./jun. 2005. 
estatuto tridimensional, isto é, para além do sujeito e do outro, há a priori uma instância terceira, o Outro, a ordem simbólica, na qual o falante, aquele que golpeia a linguagem, através da fala, já está inserido, e que está presente na articulação lingüística do sujeito, através da prova elênquica, contrafática, porém diversamente do modelo de fundamentação sugerido por Apel, em sua semiótica transcendental, posto que o Outro não é o mesmo que a comunidade ilimitada de comunicação de Apel. A noção de inconsciente epistemológico, como conjunto de premissas de argumentação que são estabelecidas por prova elênquica, indireta ou contra-fática, pode ser estabelecida a partir da diferença transcendental instituída no início da articulação do sistema de pensamento de Lacan entre, de um lado, o ego, instância da captação imaginária, fruto de alienações sucessivas, cuja matriz primeva encontra-se no estádio do espelho e, de outro lado, o sujeito, habitante do simbólico, ali inscrito e registrado, a partir de sua inevitável imersão na linguagem, cuja enzima catalizadora ou elemento possibilitador é proporcionada pelas etapas normativizadoras cumpridas no desfiladeiro do complexo de Édipo, enquanto funciona como condição de possibilidade ou plataforma a priori que institui a conexão entre o infans e a linguagem.

Trata-se, em Lacan, de compreender, relativamente à noção de função simbólica, o princípio inconsciente único em torno do qual era possível organizar a multiplicidade das situações particulares a cada sujeito (ROUDINESCO, 1994, p. 225). Este outro espaço epistemológico, solidário à compreensão da eficácia da operatividade da lógica do significante é uma ontologia transcendental, ou, antes, aquilo que vem no lugar de tal ontologia (MAJOR, 1991, p. 369). Trata-se, por conseguinte, não da produção de uma nova ontologia, mas da determinação de uma condição epistêmica. Temos em Lacan uma ontologia, porém, não no sentido estrito do saber da filosofia, mas de uma ontologia da hiância.

A utilização do termo ontologia não remete a poder compreender o campo descrito pelo saber da psicanálise como construindo ou indicando alguma ontologia ou remetendo a alguma ontologia, enquanto campo de positivação de um saber.

A referência ao termo informa antes uma negatividade, uma produção ao revés, uma efetiva impossibilidade de pensar-se em qualquer ontologia em função do sujeito encontrar-se despossuído de con-

Revista de Filosofia, Curitiba, v. 17 n.20, p. 147-163, jan./jun. 2005. 
teúdo positivo e de uma mola ${ }^{5}$ gnosiológica cartesiana que lhe permitiria produzir um saber que pudesse constituir um espaço ontológico. No espaço lacaniano, a dobra de que é constituído o humano é uma dobra hetero produzida. A reduplicação do sujeito e de sua performance cogitativa não pode ser operada aqui a partir de um pensar autônomo. No lacanismo, o sujeito, ao iniciar sua trajetória de pensamento, já se encontra inserido no interior do espaço de uma dobra, de uma clivagem, posto que ele já aparece como resultado de uma clivagem que é efetivada em seu ser, no momento mesmo de sua parturiação como sujeito humano.

Em Kant, se o humano tem à sua disposição a possibilidade de movimentar-se no mundo do simbolismo, a partir da utilização do símbolo, nem por isso está autorizado a objetivar o pensamento, de apresentá-lo enquanto objeto. Os símbolos existem para tornar discernível o que é cogitável e o que é conhecível. A existência do símbolo representa a possibilidade humana de responder à existência de um mundo numenal. O símbolo atesta ao mesmo tempo a existência de limites estritos à faculdade e à capacidade do homem de falar de si mesmo, de sua alma, sua consciência, sua psicologia e seu mundo interior. Em Lacan, trata-se de compreender que seu pensamento se lança em direção a uma interpretação lingüística do simbolismo enquanto condição da possibilidade de conhecer. Desta forma, Kant e Lacan constituem-se em elos da mesma corrente cognitiva (MAJOR, 1991, p.75).

Compreendemos, desta forma, a hipótese básica lacaniana, que percorre toda a sua obra, da anterioridade e autonomia do simbólico, em relação à fala individual do sujeito. Podemos pensar, assim, na necessidade a priori da linguagem e do simbólico como momentos do contratualismo transcendental necessário à produção e à constituição do humano, no sentido de que o simbólico funciona como o a priori do homem.

Isto implica dizer que o ser humano é instado a viver numa outra ordem de realidade instituída pela regulação a priori do simbólico. O simbólico operando como condição de possibilidade da própria gênese do humano que, a partir disto, não pode ser considerado um dado natural, mas uma descontinuidade no real. A atividade de amálgama a que Lacan submete os diversos conceitos que incorpora, parece indicar uma necessidade de atuar como hológrafo do significante, o que lhe permitiria restituir o caráter tridimensional do significante. Ou seja, para

5 Outro funcionando como mola da fala. (n.a)

Revista de Filosofia, Curitiba, v. 17 n.20, p. 147-163, jan./jun. 2005. 
além da singela compreensão da obsessão filosófica de visada cartesiana, que torna simétricos sujeito (produtor de conhecimento) e objeto tematizado (Telos do conhecimento), Lacan sinaliza a existência, ou mais propriamente a insistência, de um terceiro elemento do jogo lingüístico, que é a própria ordem simbólica, que atua como condição de possibilidade da própria existência do jogo.

Assim, Lacan atuaria como executor testamentário holográfico do significante, na medida em que sua teoria opera uma exumação do caráter fundador da ordem simbólica enquanto condição de ancoragem do humano-ser. Lacan parece pretender ocupar esta posição de reedição laica do gênesis, no sentido em que procura recriar o próprio momento de instauração do humano, que dar-se-ía, para ele, a partir do comércio inevitável com o significante.

Daí que, no caso de Lacan, a auto-imolação como testamentário holográfico do significante produziu-lhe o efeito de co-pertencer ao estilo barroco, em sua empreitada de tentar fazer o significante falar. A tarefa a que se propôs o dândi parisiense da psicanálise seria a de produzir a extração para fora da linguagem de algo que lá está preso (LACAN, 1985, p. 31). A partir da compreensão de que o ser humano situa-se para além do real que lhe é biologicamente natural, no sentido de que o humano para constituir-se como tal, deve ocupar um topos subversivo para além da plataforma do ancoradouro biológico, e passar a habitar o mundo da linguagem, sendo que esta metamorfose, esta transmutação do natural ao cultural, do biológico ao simbólico, podemos compreender que a psicanálise é teoria do desejo na sua relação ao Outro (LACAN, 1963, p. 35; 1987, p. 402).

Compreende-se, desta forma, a necessidade da produção de um espaço epistemológico específico e adequado à extração do significado da coletânea de conceitos produzidos no campo de saber da psicanálise, na medida em que a radical heteronomia do sujeito humano lhe ocasiona a ek-sistência de um hiato, de uma clivagem em si mesmo, de uma clivagem na natureza humana.

\section{II - A semiótica transcendental de Apel (1985) e Santuário (1998): a dobra no interior da linguagem.}

Apel lança as bases de sua transformação da filosofia a partir da incorporação dos achados teóricos da filosofia transcendental kantiana

Revista de Filosofia, Curitiba, v. 17 n.20, p. 147-163, jan./jun. 2005. 
somados à pragmática dos signos e a necessária referência à intersubjetividade lingüisticamente constitutiva da interpretação do mundo.

A este projeto, ele denomina de transformação semiótica da filosofia transcendental. O a priori agora instituído passa ser o da linguagem (e não mais o das condições de possibilidade do conhecimento), compreendido como a priori semiótico transcendental da mediatização dos signos e da linguagem em relação à comunidade de argumentantes.

Desta forma, para qualquer atividade filosófica, seja análise da linguagem, hermenêutica, etc., está antecipadamente pressuposta a possibilidade de comunicação universal. A necessidade da transformação semiótica da filosofia transcendental, de visada kantiana, remete a uma necessidade de incluir a questão da intersubjetividade da interpretação do mundo. Esta inserção lingüística de um sujeito no mundo, dotado de razão não monológica, mas desde sempre dialógica, representa como que uma espécie de elemento a priori indepassável. A intersubjetividade se encontra, portanto, já sempre logicamente antecipada. Temos, por conseguinte, o estabelecimento de normas de procedimento para toda a argumentação com sentido e validade, o que representa a definitiva superação do solipsismo metódico do transcendental kantiano. Esta transformação, fruto da identificação por Apel dos impasses metodológicos dos paradigmas filosóficos precedentes, suplanta a clássica pergunta kantiana pelas condições de possibilidade do conhecimento objetivo, cujo solo de verificação é remissível à idéia de uma consciência em geral, colocando a necessária pergunta pelas condições de possibilidade do acordo intersubjetivo sobre o sentido e veracidade dos enunciados.

A Aufhebung em relação à filosofia transcendental clássica é efetuada mediante a ampliação da reflexão e do conteúdo desta reflexão. Supera-se a tematização reflexiva pelas condições de possibilidade do acesso ao conhecimento de objetos (condições de possibilidade da experiência), em direção a uma reflexão estrita sobre as condições de possibilidade do conhecimento lingüisticamente formulado e intersubjetivamente válido. A tematização reflexiva destas condições, ou a explicitação dos pressupostos do argumentar válido (empiricamente, frente a uma comunidade real de argumentantes e, in the long run frente a uma comunidade ilimitada de comunicação) não pode ser efetivada com recurso aos instrumentos conceituais da lógica-formal, à metafísica dedutiva tradicional ou conhecimento (contingente) das ciências empíricas (que trabalham com o pressuposto cons-

Revista de Filosofia, Curitiba, v. 17 n.20, p. 147-163, jan./jun. 2005. 
titutivo da auto-eliminação e auto-esquecimento do sujeito agente do conhecimento e do discurso.)

Desta forma, o foco de análise e o chão de sustentação desta nova modalidade de fundamentação passam a ser não mais a consciência e a unidade transcendental da apercepção, tributárias do solipsismo metódico, mas sim o acordo intersubjetivo (qua síntese transcendental da interpretação dos signos lingüísticos) sobre a interpretação de signos num consenso intersubjetivo ilimitado.

A filosofia, diversamente do jogo de linguagem específico dos saberes parciais da ciência, não trabalha com demonstração dedutiva, mas com demonstração reflexiva, i.e. explicitação do implícito; pressupostos reconhecidamente inerentes a todo ato filosófico que se funda como tal, co-extensivo das condições de possibilidade do argumentar como tal. Esta demonstração reflexiva exigiria, por parte de Apel, a inclusão da perspectiva semiótica, o que permite ampliar o horizonte do transcendentalismo.

A semiótica transcendental de Apel implica ab initio na referência a um terceiro. Toda proposição de uma linguagem natural, por oposição às linguagens artificialmente constituídas, possui uma dupla estrutura: proposicional e performativa. Este elemento performativo reportase desde sempre a um terceiro, a um co-sujeito.

A descoberta e incorporação da dimensão pragmática no uso dialógico da linguagem permitem a instauração do silêncio dos proferimentos solipsistas através da efetiva liquidação do solipsismo autárquico. A fundamentação específica, obtida pela pragmática transcendental não é tributária de um saber autárquico e solipsista, mas é resultado da supressão de todas as atividades monológicas que pretenderiam derivar e deduzir do movimento interior das atividades da consciência o molde a ser aplicado ao mundo (objetual-psíquico-teórico) para obter uma fundamentação irrecusável, porém falaciosa.

Apel nos fala de condições constitutivas do conhecimento válido que, ampliando e radicalizando a metodologia e o paradigma kantianos, são alcançadas pela proposta do paradigma da semiótica-transcendental. Assim, qualquer tentativa de contestar as implicações do a priori argumentativo conduz, necessariamente, à auto-contradição performativa.

Vemos, desta forma, que as implicações do princípio da argumentação são mais fundamentais do ponto de vista filosófico e transcendental que o a priori dos esquemas categoriais do possível conhecimen-

Revista de Filosofia, Curitiba, v. 17 n.20, p. 147-163, jan./jun. 2005. 
to de um mundo de objetos. Elas não se referem a uma estrutura de conteúdos proposicionais de atos de conhecimento afirmados como a priori necessários. Mas se referem às pressuposições de todo argumentar com sentido.

Trata-se, em Apel, do segundo giro copernicano, ou de uma reflexão transcendental do sujeito, para além de sua consciência sintética ou dos juízos sintéticos engendrados pela consciência transcendental solipsista, buscando determinar as condições de possibilidade da formulação discursiva, dialógica, de uma fundamentação discursiva com sentido, elementos formuláveis a partir de um a priori indepassável, que é a comunidade ilimitada de comunicação.

No discurso filosófico-reflexivo, encontramos as condições formais de toda argumentação e fundamentação enquanto tais e, com isso, o momento de incondicionalidade e universalidade inerente à razão. A apercepção interna da consciência, como síntese da apercepção - o eu penso que acompanha todas as minhas representações no paradigma da filosofia da consciência, é superado pela necessária referência, à comunidade ilimitada de comunicação, contra-faticamente antecipada, como condição interna de validade do discurso.

No caso de que alguém pretenda faticamente, empiricamente, negá-la ou de indicar sua inexistência ou não necessidade de ser pressuposta em todo ato argumentativo de qualquer falante, estará incorrendo naquilo que Apel denomina de autocontradição performativa, pois estará tentando negar o pressuposto contido em seu próprio discurso. A noção de comunidade ilimitada de comunicação não tem um caráter empírico fático, mas o seu não reconhecimento fático implica numa autocontradição pragmática.

A auto-referência somente pode ser empreendida e efetivada em função da virtual antecipação (contrafática) da comunidade ilimitada de comunicação, i.e., a auto-referência somente é justificável qua atitude filosófica numa situação, num ambiente performativo (dupla referência do discurso). A intuição monológica das essências pretendia ingenuamente funcionar independentemente da linguagem, descartando a inteligência lingüística conceitual da comunidade ilimitada de comunicação. Temos assegurada, desta forma, uma validade pública ao jogo lingüístico transcendental de uma comunidade de comunicação.

O diálogo argumentativo está ligado à dupla estrutura performativo-proposicional dos atos lingüísticos. Tal discurso, na medida em

Revista de Filosofia, Curitiba, v. 17 n.20, p. 147-163, jan./jun. 2005. 
que está vinculado à crítica e à satisfação virtual das pretensões de sentido e de verdade, depende evidentemente das condições normativas, cuja validade, assim como as pretensões de sentido e de verdade dos atos de linguagem, está submetida ao critério de uma capacidade ilimitada de consenso. Contestar isto expõe aquele que argumenta a se contradizer (APEL, 1994).

O discurso apeliano na semiótica transcendental, que opera uma transformação da filosofia, situa-se no espaço interno da dobra e da clivagem. Ele procura não apenas descrever a atividade da filosofia como constituída por uma dobra, mas, ao mesmo tempo, operar filosoficamente no espaço mesmo desta dobra e desta diferença. Em Apel, vemos que esta dobra tem caráter e significação transcendental, superando, contudo, o esquema clássico kantiano.

\section{III - Gadamer e a hermenêutica filosófica: o exercício filosó- fico no interior da dobra.}

A hermenêutica filosófica de Gadamer é uma hermenêutica parida em ventre hegeliano, onde Hegel aparece ali apenas como sombra e não como primeiro motor (GADAMER, 1986, apud DOSTAL, 2002, p. 262) ${ }^{6}$. Em Gadamer não está em jogo repor, pela ciência da lógica, 0 Telos de um espírito absoluto nem mostrar dialeticamente as etapas de efetivação do conceito na história.

Trata-se de apresentar o humano como fenômeno solidário ao acontecer da tradição, da compreensão e da linguagem. O humano aparece aqui ao inverso da racionalidade solipsista moderna que, a partir de um cogito, põe o objeto e produz o conhecimento. Aqui o humano surge como efetivado pelo acontecer de uma experiência que o ultrapassa.

Gadamer centra a formulação de sua hermenêutica filosófica na rejeição do subjetivismo e do relativismo e no privilégio concedido à compreensão linguisticamente mediada do acontecer da tradição. A hermenêutica filosófica de Gadamer estabelece e funda um solo adequado à interpretação e à compreensão e rejeita qualquer possibilidade de que esta compreensão possa ser atingida pela aplicação de um conjunto de

6 Gadamer situa sua obra apontando para um lugar "entre a fenomenologia e a dialética" - mesmo título de uma autocrítica escrita em 1986 (GW 2,3-26).

Revista de Filosofia, Curitiba, v. 17 n.20, p. 147-163, jan./jun. 2005. 
regras. Esta recusa do metodologismo, enquanto ação de um mecanismo neutro de produção de significado, implica na ênfase e na prioridade da compreensão ao caráter dialógico da linguagem como mediação e meio produtor de sentido e de sua apropriação.

$\mathrm{O}$ fenômeno hermenêutico e o acontecer da linguagem, estreitamente relacionados à finitude de nossa experiência histórica, fazem com que sejamos seres que sempre vimos de muito antes e chegamos até muito depois. Para Gadamer, seguindo o rastro da linguagem veremos o que é real, para mais além da consciência de cada um. Neste modo de estruturação de nossa própria experiência, a linguagem não copia a estrutura do ser, antes mostra o modo de ser finito do humano.

Já em Ser e Tempo, Heidegger havia retificado a noção de verdade como vinculada à coerência de enunciados, mostrando que há um conceito mais originário de verdade ligado ao modo de ser do homem no mundo. Daí a elaboração da hermenêutica da facticidade do Dasein como locus de mostração desta verdade.

No segundo Heidegger, a noção de verdade aparece vinculada à linguagem da poesia e ligada a eventos e processos nos quais e através dos quais ambos, as coisas e o mundo e aquilo que é dito deles, são revelados num único e mesmo instante. Conforme testemunho do próprio Gadamer (1997, p. 46-47) ${ }^{7}$, a tarefa a que se propôs na produção de sua hermenêutica filosófica consiste na elaboração e desenvolvimento das concepções do Heidegger II.

Gadamer amplia a intuição heideggeriana da verdade vinculada à poesia e à arte e o conceito de verdade como desvelamento, fenômeno no qual já estamos envolvidos e que não podemos tornar totalmente transparente. A isto acrescenta as noções centrais de experiência e do caráter lingüístico de toda compreensão, estreitamente vinculados ao sopro hegeliano que infunde a sua utilização da hermenêutica da facticidade do Dasein.

A compreensão sempre e somente pode ser efetivada pelo diálogo. Desta forma, Gadamer toma distância da filosofia da reflexão de Hegel que visa à totalidade, vinculando-se à hermenêutica da finitude,

7 "...minha filosofia hermenêutica busca precisamente aderir à linha de questionamento do ensaio de Heidegger a Origem da obra de arte, e ao último Heidegger e tornar isto acessível numa nova maneira...devo deixar a outros a decisão se o caminho que eu percorri pode reivindicar a fidelidade, pelo menos em algum grau, com a própria aventura heideggeriana do pensar".

Revista de Filosofia, Curitiba, v. 17 n.20, p. 147-163, jan./jun. 2005. 
embora advogue a infinitude do processo de produção da compreensão. A diferença ontológica entre Erfahrung, como consciência histórica comum composta de uma multiplicidade de vozes que ecoam do passado e relativa ao Mitwelt, ao mundo que todos temos em comum, e Erlebnis, como momento irrepetível da experiência em que se efetiva e se desvela o vivido para o humano individual, não é pressuposta como disparador do ato filosófico, mas trabalhada no interior da dobra gadameriana, onde é mantida acesa e viva a tensão entre estes dois momentos.

A hermenêutica filosófica de Gadamer, em sua marcha fenomenológica, empreende a operação de produzir o diálogo interno entre este dois momentos, não através do mecanismo da dialética hegeliana, mas de uma hermenêutica da finitude que comporta, sem contradição, a infinitude do compreender linguisticamente mediatizado. Este projeto faz com que Gadamer se distancie do solo de uma diferença ontológica de cunho heideggeriano onde esta diferença é captada no pensamento e, ato contínuo, reposta na linguagem. Gadamer caracteriza sua diferença com Heidegger da seguinte forma: "Este foi meu caminho - eu disse a Heidegger que a linguagem não é a palavra que possui poder; linguagem é diálogo"8.

A ontologia de Verdade e Método é uma ontologia da linguagem. A fusão de horizontes que acontece na compreensão é uma realização da linguagem. Gadamer nos mostrou que o ato de falar e de conversar não se refere a nós, enquanto utilizamos a linguagem, mas à linguagem operando em nós de tal forma que a verdade acontece (DOSTAL, 2002, p. 254).

O objetivo da ciência é o de objetificar a experiência de modo que ela não contenha mais nenhum elemento histórico (GADAMER, 2001, p. 346). Desta forma, a ciência desqualifica o conceito de experiência reduzindo-o ao elemento repetível e manipulável. Contudo, a hermenêutica gadameriana nos mostra que experiência é experiência da finitude humana. A verdadeira experiência é aquela que permite ao homem dar-se conta de sua própria finitude. O homem experimentado é aquele que sabe que nada retorna (GADAMER, 2001, p. 357). A experiência hermenêutica está vinculada à tradição. Mas tradição não pode ser com-

8 This was my way - that I told Heidegger that language is not the powerful word; language is reply". Journal of the British Society for Phenomenology n. 26, 1995, p. 123.

Revista de Filosofia, Curitiba, v. 17 n.20, p. 147-163, jan./jun. 2005. 
preendida como um objeto. Tradição é linguagem. Desta forma se conectam, no interior do exercício filosófico da dobra gadameriana os conceitos de vida, experiência, expressão, compreensão e hermenêutica. Uma experiência, que experimenta realidade é ela própria real (GADAMER, 2001, p. 346).

Gadamer empreende uma atividade filosófica situada no interior da fenomenologia, na medida em que empreende uma descrição da experiência humana da compreensão. A experiência hermenêutica assim descrita em sua fenomenologia coloca sua tarefa como eminentemente filosófica na medida em que se trata de descrever e recuperar na linguagem aquilo que acontece conosco para além daquilo que queremos ou fazemos (GADAMER, 2001, p. 28).

\section{Referências}

APEL, Karl-Otto. La transformación de la filosofia. Madrid: Taurus, v. 1, 1985.

. Le logos propre au langage humain. Paris: De l'éclat. 1994. DAWKINS, R. The blind watchmaker. Essex: Longman, 1986.

. The selfish gene. 2nd ed. Oxford: OUP, 1989.

DOSTAL, R. J. The Cambridge companion to Gadamer. Cambrige: Cambrige Univertsity Press, 2002.

EVANS, D. Dictionary of lacanian psychoanalysis. London: Routledge, 1997.

GADAMER, H.G. Truth and method. $2^{\text {nd }}$. ed. Transl. Weinsheimer, J. and Marshall, D.G. London: Sheed \& Ward. 2001.

HAHN, Lewis Edwin (ed.). Reflections on my philosophical journey. Trans. by Richard E. Palmer. In: ___ . The philosophy of HansGeorg Gadamer. Chicago: Open Court, 1997. (Library of Living Philosophers,24).

LACAN, J. Escritos. Rio de Janeiro, RJ: Jorge Zahar, 1995. Publicado originalmente em 1960. 
. O Seminário, Livro 10: a angústia. [S. l.:s. n.], 1963. [inédito].

. O Seminário, Livro 17: o avesso da psicanálise. Rio de Janeiro, RJ: Jorge Zahar, 1992.

. O Seminário, Livro 2: o eu na teoria de Freud e na técnica da psicanálise. Rio de Janeiro, RJ: Jorge Zahar, 1987.

\section{5.}

. O Seminário, Livro 20: mais, ainda. Rio de Janeiro, RJ: Zahar,

MAJOR, R. et al. Lacan avec les philosophes. Paris: Albin Michel, 1991.

MULER, John P. et al. RICHARDSON, William J. Lacan and language. Madison(CT): International Universities Press, 1994.

ROUDINESCO, E. Jacques Lacan: esboço de uma vida, história de um sistema de pensamento. São Paulo, SP: Cia das letras, 1994.

STEIN, E. Vida humana, um conceito da antropologia filosófica. Revista Veritas, Porto Alegre: v. 48, n. 4, p. 519-531, dez. 2003.

. Pensar é pensar a diferença. Ijuí: Unijuí: 2002.

SANTUARIO, LC. A condição epistêmica da psicanálise lacaniana. Revista Veritas, Porto Alegre: v. 48, n .2, p. 277-289. EDIPCURS. jun, 2003.

. Lei do desejo: epistemologia da psicanálise lacaniana. Caxias do Sul: EDUCS. 2004.

A transformação da filosofia: a semiótica transcendental de Karl-Otto Apel. Caxias do Sul: EDUCS, 1998.

Recebido em: Received in: 22/ 02/ 2005 Aprovado em: Approved in: 21/03/2005

Revista de Filosofia, Curitiba, v. 17 n.20, p. 147-163, jan./jun. 2005. 